\title{
DETERMINATION OF STATURE FROM CEPHALIC INDICES AMONG OKUN AND EBIRA ETHNIC GROUPS OF KOGI STATE IN NIGERIA.
}

Alabi AS, Adeleye JT, Kareem SB, Lewu FS, Oyewopo AO

Correspondence to A.S Alabi, dradealabi@gmail.com . Department of Anatomy, Faculty of Basic Medical Sciences, University of Ilorin. PMB 1515, Ilorin, Kwara State. Nigeria. +2348030575490

\begin{abstract}
Cephalic index is an important feature that characterizes different races. The study aimed at comparing the cephalic indices between the two genders and to determine the stature among Okun and Ebira ethnic groups in Nigeria. The subjects were measured for cephalic length, breadth and subject height and the cephalic indices were calculated by dividing the cephalic breadth by cephalic length, and then multiply by 100. 844 subjects of Okun and Ebira origin of Kogi state were measured, 211 males and 211 females for each tribe were measured. Fischer's formula was used to determine the sample size because the population size is $>10,000$. The cephalic breadth and length was measured using a spreading caliper and the subject height was measured with a stadiometer. The data was analyzed using Pearson's Chisquare analysis test for association, trends and distribution difference of the pattern (confidence level at $95 \%$ ). The mean cephalic indices of both Okun and Ebira ethnic group were $>75$ and $>70$ which belongs to mesocephalic and doliocephalic group respectively. There were significant differences in cephalic indices between both ethnic groups $(p<0.001)$. There was no significant difference in cephalic indices between males and females of each ethnic group. Stature was better predicted from cephalic indices for Ebira males $(r=0.386)$ when compared to the Ebira females $(r=0.127)$, Okun males $(r=0.296)$ and Okun females $(r=0.268)$. All predictions were significant except for Ebira females.
\end{abstract}

Keywords: mesocephalic, doliocephalic, cephalic indices, stature, sex.

\section{INTRODUCTION}

Cephalic index anthropometry is important features which characterize different races. Some ethnic groups have similarities and differences in cephalic indices. It is a widely used anthropometric parameter in determining the racial variation and unusually used to determine sex differences, especially in individuals whose identity is unknown (Shah et al., 2004). Head dimension changes followed pattern in different population (Kelly et al., 1999). Head growth occurs as its most rapid rate during the first year of life. The head grows to almost $80 \%$ of the adult size during the first year of life then grows at slower pace. If the head is too large or growing too quickly or on the other hand if the head is too slow or growing too slowly, these are signs of possible problems (Danborno et al., 1997). The measurements of the head in anthropometric study are usually carried out carefully by understanding some anthropometric landmarks which must be maintained in a better orientation (Iscan, 2001; Iscan, 2005). On basis of cephalic index, head shapes are grouped into four international categories, which are dolichocephal, brachycephal, mesocephal, and hyperbrachycephal (Williams, 1995). The first classification based on cranial morphology is attributed to the professor of anatomy Anders Retzius (1840). An index of less than 75 means that the skull is long and narrow when seen from the top such skull is called dolichocephalic and are typical of Australian aborigines and native Southern Africans. An index of 75 -80 means that the skull is nearly oval; such skulls are called mesaticephalic and are typical of Europeans and the Chinese. A skull having an index of over 80 is broad and short and is called brachycephalic; such skulls are common among Mongolians and 
the Andaman islanders (Nair, 2014). A study on cephalic indices of Igbos and Ijaw ethnic groups; the Ijaw males has a mean of 80.98 and Ijaw females 78.04, the Ijaw males are in brachycephalic group while the Ijaw females are in mesocephalic group (Oladipo et al., 2006). A study on the estimation of stature from cephalic parameters in south- eastern Nigeria population was done which the findings showed that the cephalic indices are positively and significantly correlated with stature (Ewunonu and Anibeze, 2013). Cephalic index has been researched on by several authors for gender, ethnicity, race, growth, age and clinical uses, hereby classifying the head sizes but there is less research work on the relationship between cephalic indices with respect to stature amongst Okun and Ebira ethnic groups of Kogi state in Nigeria. The research is aimed at comparing the cephalic indices between the two genders and to determine stature from the cephalic indices among the Okun and Ebira ethnic groups of Kogi state in Nigeria. The cephalic indices sexually dimorphic or not among both ethnic groups. Finally, classifying the head sizes and shape among the both ethnic groups.

\section{MATERIALS AND METHOD}

Sample sizes of eight hundred and forty-four subjects were used from the population of both ethnic groups of Kogi state in Nigeria for this study. Two hundred and eleven males and two hundred and eleven females of each ethnic group were used. Fischer's formula was used to determine the sample size because the population size is $>10,000$.

$$
\mathrm{S}=\frac{\mathrm{z}^{2} \times \mathrm{p} \times \mathrm{q}}{\mathrm{d}^{2}}
$$

Subjects belonged to either Okun or Ebira ethnic group of Kogi state, Nigeria traced to grandparents within adults from 18 -65 years of age. Subjects must have been born and breed in Nigeria to avoid any environmental changes on the subjects. Subjects with obstructive hairstyles were not used. Subjects with limbs deformity or craniofacial deformity or had previous surgery was not included in the study. The research is aimed at comparing the cephalic indices between the two genders and to determine stature among the Okun and Ebira ethnic groups of Kogi state. The subjects were made to stand and sit at various points in time at comfort to take all the measurements after adequate explanation of the procedure. The procedure was neither painful nor harmful to the volunteers. Extreme care was taken to avoid any form of discomfort to subjects. The study was conducted with the understanding and the consent of the subjects.

Anthropometric measurements: Cephalic length: the straight distance between glabella and inion.

Glabella: the point midway between the two supercilliary ridges. Inion: the external occipital protuberance. Cephalic breadth: the maximum transverse diameter between two fixed points over the parietal bones. Cephalic index is calculated as;

$\frac{\text { Cephalic breadth }}{\text { Cephalic length }} \times 100$ 
Anatomy Journal of Africa. 2019. Vol 8 (2): 1626 - 1634.

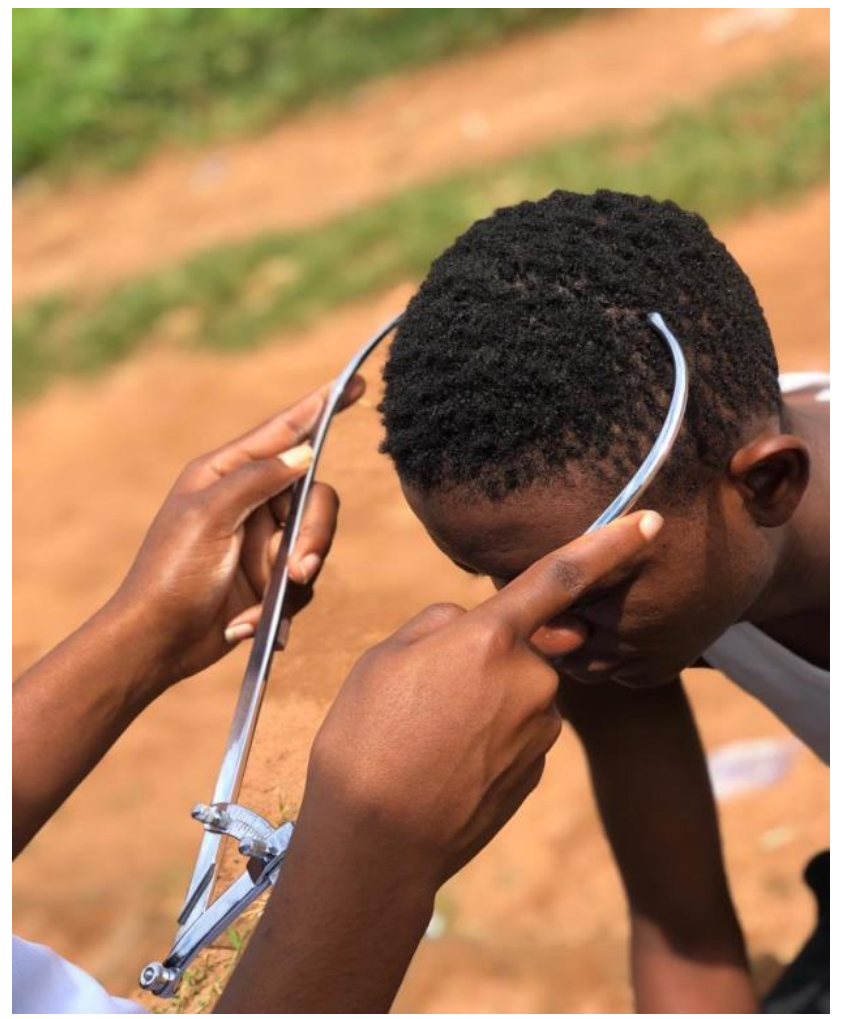

Figure 1: Measurement of the cephalic breadth using a spreading caliper.

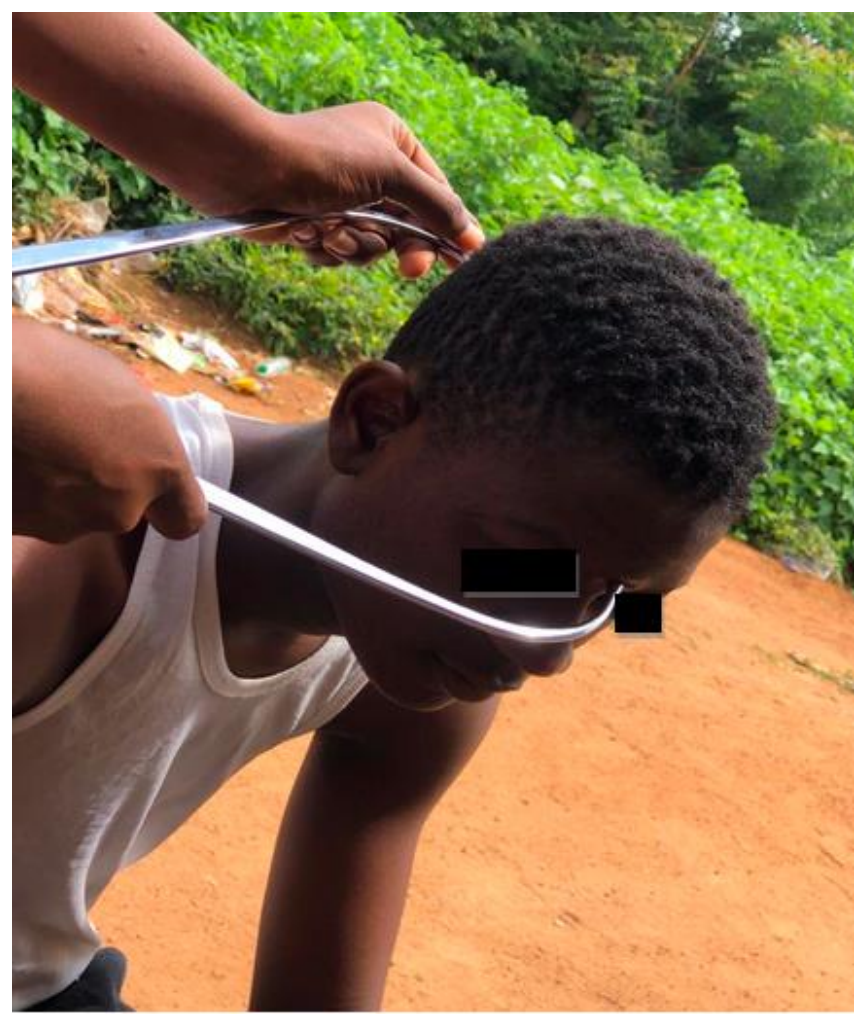

Figure 2: Measurement of the cephalic length using a spreading caliper.

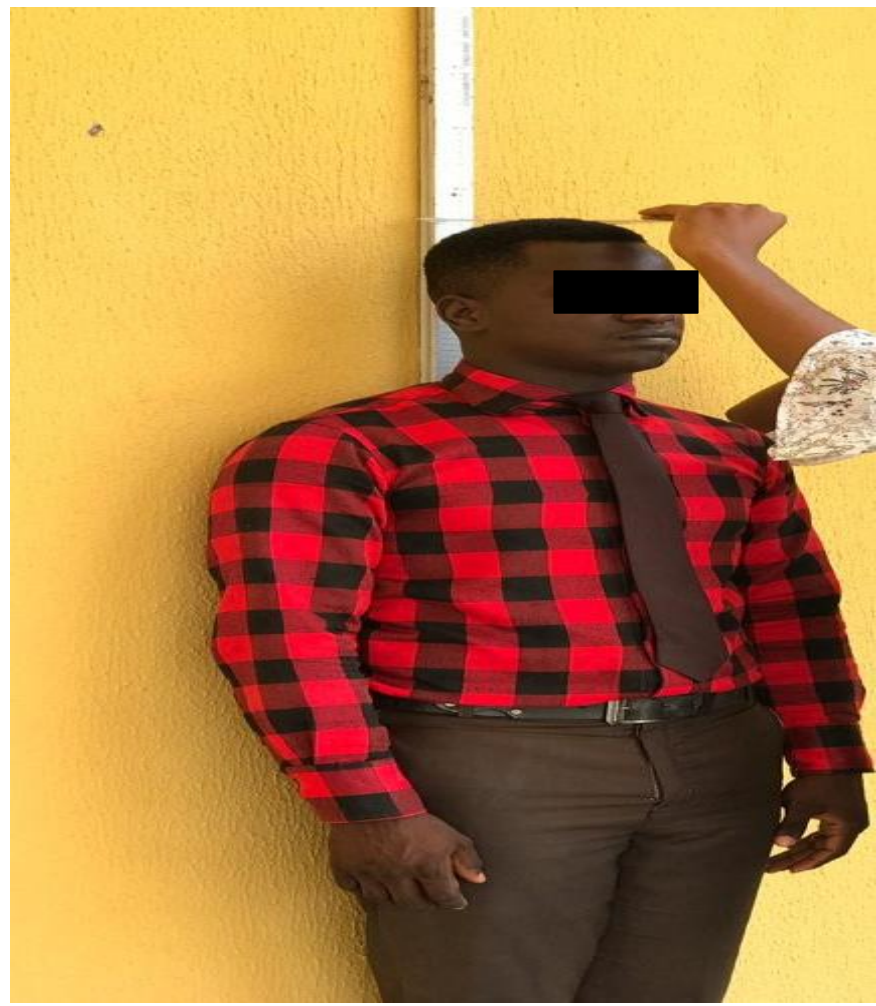

Figure 3: Measurement of the height using a stadiometer. 
The stature was measured in a standing position using a stadiometer. Measurements were taken by subjects being asked to stand in an upright position. All dimensions of cephalic breadth, length was to be measured using a spreading caliper while stature measured using stadiometer. All measurements were taken by one observer to avoid error. To improve accuracy, all measurements were taken twice and the average value recorded as the main value. All measurements were centimeters $(\mathrm{cm})$.

SPSS version 21 was used to analyze the data. Descriptive statistics was used to appropriately categorize demographic frequency and distribution of patterns. Pearson's Chi-square analysis test for association, trends and distribution difference of the pattern (confidence level at 95\%).

\section{RESULTS}

The mean values of males and females in the different ethnic were presented in Table 1a. The Okun males and females had the larger head breadth $14.45 \pm 0.73 \mathrm{~cm}$ and $14.05 \pm 0.78$ respectively, when compared to the Ebira males; $13.41 \pm 0.70 \mathrm{~cm}$ and female; $12.88 \pm 0.74 \mathrm{~cm}$.

Table 1a. Descriptive characteristics of cephalic dimensions and index among the tribes stratified by sex.

\begin{tabular}{|c|c|c|c|c|c|}
\hline Variable & Tribe/Sex & $\mathrm{N}$ & Mean \pm S.D & Minimum & Maximum \\
\hline \multirow{5}{*}{$\begin{array}{l}\text { CEPHALIC } \\
\text { BREADTH }(\mathrm{cm})\end{array}$} & Ebira (M) & 211 & $13.41 \pm 0.70$ & 11 & 15 \\
\hline & Ebira (F) & 211 & $12.88 \pm 0.74$ & 11 & 15 \\
\hline & Okun (M) & 211 & $14.45 \pm 0.73$ & 12 & 17 \\
\hline & Okun (F) & 211 & $14.05 \pm 0.78$ & 12 & 16 \\
\hline & Total & 844 & $13.70 \pm 0.95$ & 11 & 17 \\
\hline \multirow{5}{*}{$\begin{array}{l}\text { CEPHALIC } \\
\text { LENGTH }(\mathrm{cm})\end{array}$} & Ebira (M) & 211 & $18.91 \pm 0.83$ & 17 & 21 \\
\hline & Ebira (F) & 211 & $18.23 \pm 0.74$ & 16 & 20 \\
\hline & Okun (M) & 211 & $18.80 \pm 0.93$ & 16 & 21 \\
\hline & Okun (F) & 211 & $18.23 \pm 0.84$ & 16 & 20 \\
\hline & Total & 844 & $18.54 \pm 0.89$ & 16 & 21 \\
\hline \multirow{5}{*}{$\begin{array}{l}\text { CEPHALIC } \\
\text { INDICES (\%) }\end{array}$} & Ebira (M) & 211 & $71.04 \pm 4.45$ & 57.89 & 83.33 \\
\hline & Ebira (F) & 211 & $70.77 \pm 4.58$ & 60 & 88.2 \\
\hline & Okun (M) & 211 & $77.00 \pm 4.40$ & 60 & 88.24 \\
\hline & Okun (F) & 211 & $77.28 \pm 5.16$ & 63.16 & 88.24 \\
\hline & Total & 844 & $74.02 \pm 5.60$ & 57.89 & 88.24 \\
\hline
\end{tabular}

The Ebira males had the largest head length $18.91 \pm 0.83$. The Okun males had a larger head length $18.80 \pm 0.93$ while compared to Okun females head length $18.23 \pm 0.84$ and Ebira females head length $18.23 \pm 0.74$. The Okun females had larger cephalic indices 77.28 \pm 5.16 and Okun males $77.00 \pm 4.40$, then Ebira male and female cephalic indices; $71.04 \pm 4.45$ and $70.77 \pm 4.58$ respectively. Table $1 \mathrm{~b}$. Compared the dimensions of both sexes of both tribes and found that the difference in the cephalic breadth between the different sexes of both tribes was statistically significant $(P<0.001)$. 
Table 1b. Post Hoc test of multiple comparison of the cephalic dimensions and index between males and females of both tribes.

\begin{tabular}{|c|c|c|c|c|}
\hline Dependent Variable & I & J & Mean Difference (I-J) & P-value \\
\hline \multirow{6}{*}{$\begin{array}{l}\text { CEPHALIC } \\
(\mathrm{cm})\end{array}$} & \multirow[t]{3}{*}{ Ebira (M) } & Ebira (F) & 0.531 & $<0.001$ \\
\hline & & Okun (M) & -1.043 & $<0.001$ \\
\hline & & Okun (F) & -0.645 & $<0.001$ \\
\hline & \multirow[t]{2}{*}{ Ebira (F) } & Okun (M) & -1.573 & $<0.001$ \\
\hline & & Okun (F) & -1.175 & $<0.001$ \\
\hline & Okun (M) & Okun (F) & 0.398 & $<0.001$ \\
\hline \multirow[t]{6}{*}{ CEPHALIC LENGTH (cm) } & \multirow[t]{3}{*}{ Ebira (M) } & Ebira (F) & 0.678 & $<0.001$ \\
\hline & & Okun (M) & 0.109 & 0.744 \\
\hline & & Okun (F) & 0.682 & $<0.001$ \\
\hline & \multirow[t]{2}{*}{ Ebira (F) } & Okun (M) & -0.569 & $<0.001$ \\
\hline & & Okun (F) & 0.005 & 1.000 \\
\hline & Okun (M) & Okun (F) & 0.573 & $<0.001$ \\
\hline \multirow[t]{6}{*}{ CEPHALIC INDICES (\%) } & \multirow[t]{3}{*}{ Ebira (M) } & Ebira (F) & 0.275 & 0.989 \\
\hline & & Okun (M) & -5.954 & $<0.001$ \\
\hline & & Okun (F) & -6.237 & $<0.001$ \\
\hline & \multirow[t]{2}{*}{ Ebira (F) } & Okun (M) & -6.228 & $<0.001$ \\
\hline & & Okun (F) & -6.512 & $<0.001$ \\
\hline & Okun (M) & Okun (F) & -0.284 & 0.991 \\
\hline
\end{tabular}

Ebira males had significantly larger cephalic breadth than Ebira females $(\mathrm{MD}=0.531$; $P<0.001)$, but smaller dimensions when compared to Okun males and females (MD= 1.043; $P<0.001)$. The Ebira females also had narrower cephalic breadth when compared to Okun males and females $(P<0.001)$, while the Okun males had a larger dimension than their females $(P<0.001)$. The Ebira males has significant larger cephalic length than Ebira females $(p<0.001)$, larger when compared to Okun males and females $(p<0.001)$. The Ebira female's cephalic length was not significantly different from Okun female's cephalic length $(p=1)$ but smaller when compared to Okun males $(p<0.001)$. The cephalic indices differences between the Ebira males and females were not statistically significant $(p \leq 1)$, also the differences in the cephalic indices were not significant between the Okun males and females $(p \leq 1)$. The cephalic indices between the Ebira males and Okun males were statistically different $(p<0.001)$, also when compared to Okun females $(p<0.001)$. The Ebira females and Okun females' cephalic indices were statistically different $(p<0.001)$.

Table 2a. Correlation and accuracy of predictors for stature. 
Anatomy Journal of Africa. 2019. Vol 8 (2): 1626 - 1634.

\begin{tabular}{|l|l|l|l|}
\hline Model & R & R-Square & $\begin{array}{l}\text { Adjusted R- } \\
\text { Square }\end{array}$ \\
\hline Ebira Male & 0.386 & 0.149 & 0.136 \\
\hline Ebira Female & 0.127 & 0.016 & 0.002 \\
\hline Okun Male & 0.296 & 0.088 & 0.074 \\
\hline Okun Female & 0.268 & 0.072 & 0.058 \\
\hline
\end{tabular}

Table 2b: Analysis of Variance (ANOVA) for significance of the predictor variables in the model

\begin{tabular}{|l|l|l|l|l|l|}
\hline Model & Sum of Squares & Df & $\begin{array}{l}\text { Mean } \\
\text { Square }\end{array}$ & F-value & P-value \\
\hline Ebira Male & 1817.79 & 3 & 605.93 & 12.047 & 0.000 \\
\hline Ebira Female & 122.95 & 3 & 40.98 & 1.126 & 0.339 \\
\hline Okun Male & 1054.60 & 3 & 351.53 & 6.629 & 0.000 \\
\hline Okun Female & 601.35 & 3 & 200.45 & 5.338 & 0.001 \\
\hline
\end{tabular}

Table 2c: Analysis of variance (ANOVA) for significance of the predictor variables in the model.

\begin{tabular}{|l|l|l|l|l|}
\hline \multirow{2}{*}{ Model } & \multicolumn{2}{l}{$\begin{array}{l}\text { Unstandardized } \\
\text { Coefficients }\end{array}$} & \multirow{2}{*}{ t-value } & \\
\cline { 2 - 4 } & B & Std. Error & \\
\hline (Constant) & 23.632 & 46.648 & 0.507 & 0.613 \\
\hline CEPHALIC BREADTH $(\mathrm{cm})$ & -3.730 & 3.275 & -1.139 & 0.256 \\
\hline CEPHALIC LENGTH $(\mathrm{cm})$ & 6.752 & 2.367 & 2.853 & 0.005 \\
\hline CEPHALIC INDICES & 1.012 & 0.622 & 1.629 & 0.105 \\
\hline \multicolumn{5}{|l|}{} \\
\hline (Constant) & 146.577 & 40.619 & 3.609 & 0.000 \\
\hline CEPHALIC BREADTH $(\mathrm{cm})$ & 1.089 & 3.046 & 0.358 & 0.721 \\
\hline CEPHALIC LENGTH $(\mathrm{cm})$ & 0.285 & 2.181 & 0.131 & 0.896 \\
\hline CEPHALIC INDICES & -0.040 & 0.551 & -0.073 & 0.942 \\
\hline \multicolumn{5}{|l|}{} \\
\hline (Constant) & 163.819 & 62.995 & 2.601 & \\
\hline CEPHALIC BREADTH $(\mathrm{cm})$ & 1.992 & 4.165 & 0.478 & 0.010 \\
\hline CEPHALIC LENGTH $(\mathrm{cm})$ & 0.680 & 3.251 & 0.209 & 0.835 \\
\hline CEPHALIC INDICES & -0.439 & 0.790 & -0.555 & 0.579 \\
\hline & & & & \\
\hline (Constant) & 169.543 & 44.100 & 3.845 & 0.000 \\
\hline CEPHALIC BREADTH $(\mathrm{cm})$ & 3.223 & 2.979 & 1.082 & 0.281 \\
\hline CEPHALIC LENGTH $(\mathrm{cm})$ & -0.521 & 2.418 & -0.215 & 0.830 \\
\hline CEPHALIC INDICES & -0.537 & 0.528 & -1.016 & 0.311 \\
\hline
\end{tabular}

Table 3a: Head shape type (Ebira Male vs. Ebira Female) \begin{tabular}{|l|l|l}
\hline Tribe/Sex & Head type \\
\hline
\end{tabular} test of association 
Anatomy Journal of Africa. 2019. Vol 8 (2): 1626 - 1634.

\begin{tabular}{|l|l|l|l|l|l|l|l|}
\hline & Dolio & Meso & Brachy & Hyperbrachy & Df & $\begin{array}{l}\text { chi- } \\
\text { square }\end{array}$ & $\begin{array}{l}\text { P- } \\
\text { value }\end{array}$ \\
\hline Ebira M & $184(87.2)$ & $21(10.0)$ & $6(2.8)$ & $0(0)$ & 3 & 5.412 & 0.144 \\
\hline Ebira F & $173(82.0)$ & $34(16.1)$ & $\begin{array}{l}3 \\
(.4 \%)\end{array}$ & $1(0.5)$ & & & \\
\hline Total & $357(84.6)$ & $55(13.0)$ & $9(2.1)$ & $1(0.2)$ & & & \\
\hline
\end{tabular}

Table 3b: Head shape type (Okun Male vs. Okun Female)

\begin{tabular}{|l|l|l|l|l|l|l|l|}
\hline \multirow{2}{*}{ Tribe/Sex } & \multicolumn{2}{|l|}{ Head type } & \multicolumn{2}{l|}{ test of association } \\
\cline { 2 - 8 } & Dolio & Meso & Brachy & Hyperbrachy & Df & chi-square & P-value \\
\hline Okun M & $65(30.8)$ & $103(48.8)$ & $39(18.5)$ & $4(1.9)$ & 3 & 4.541 & 0.209 \\
\hline Okun F & $67(31.8)$ & $93(44.1)$ & $39(18.5)$ & $12(5.7)$ & & & \\
\hline Total & $132(31.3)$ & $196(46.4)$ & $78(18.5)$ & $16(3.8)$ & & & \\
\hline
\end{tabular}

Table 3c: Head shape type (Ebira Male vs. Okun Male)

\begin{tabular}{|l|l|l|l|l|l|l|l|}
\hline \multirow{2}{*}{ Tribe/Sex } & \multicolumn{4}{|l|}{ Head type } & \multicolumn{3}{l|}{ test of association } \\
\cline { 2 - 8 } & Dolio & Meso & Brachy & Hyperbrachy & Df & chi-square & P-value \\
\hline Ebira M & $184(87.2)$ & $21(10)$ & $6(2.8)$ & $0(0)$ & 3 & 139.297 & $<0.001$ \\
\hline Okun M & $65(30.8)$ & $103(48.8)$ & $39(18.5)$ & $4(1.9)$ & & & \\
\hline Total & $249(59.0)$ & $124(29.4)$ & $45(10.7)$ & $4(0.9)$ & & & \\
\hline
\end{tabular}

Table 3d: Head shape type (Ebira Female vs. Okun Female)

\begin{tabular}{|l|l|l|l|l|l|l|l|}
\hline \multirow{2}{*}{ Tribe/Sex } & \multicolumn{3}{|l|}{ Head type } & \multicolumn{3}{l|}{} & \multicolumn{2}{l|}{ test of association } \\
\cline { 2 - 7 } & Dolio & Meso & Brachy & Hyperbrachy & Df & $\begin{array}{l}\text { chi- } \\
\text { square }\end{array}$ & $\begin{array}{l}\text { P- } \\
\text { value }\end{array}$ \\
\hline Ebira F & $173(82.0)$ & $34(16.1)$ & $3(.4 \%)$ & $1(0.5)$ & 3 & 114.391 & $<0.001$ \\
\hline Okun F & $67(31.8)$ & $93(44.1)$ & $39(18.5)$ & $12(5.7)$ & & & \\
\hline Total & $240(56.9)$ & $127(30.1)$ & $42(10.0)$ & $13(3.1)$ & & & \\
\hline
\end{tabular}

Tables 2a-c shows the correlation coefficient ( $r$ ) showed that stature was better predicted for the Ebira males $(r=0.386)$, when compared to the Ebira female $(r=0.127)$, Okun males $(r=0.296)$ and Okun females $(r=0.268)$. All predictions were significant except for Ebira female $(P=0.339)$. Tables 3a-3d shows Ebira males $(87.2 \%)$ and females $(82.0 \%)$ were predominantly doliocephalic and the difference was not sex associated $\left(X^{2}=5.412 ; \mathrm{P}=0.144\right)$.
The distribution for the Okun males (48.8\%) and females $(44.1 \%)$ were predominantly mesocephalic with a mix of doliocephalic (30\%) males and females (31.8\%). The differences were not sex associated $\left(X^{2}=4.541 ; P=\right.$ 0.209).The head type in Ebira males and females was significantly different from their Okun counterpart; males $\left(X^{2}=139.297 ; \mathrm{P}<0.001\right)$ and females $\left(X^{2}=114.391 ; P<0.001\right)$.

\section{DISCUSSION}


This study has contributed that cephalic indices and stature of sexes of both ethnic groups are useful anatomical structure which plays important roles in forensic investigations, clinical practices and serves as basis for further comparison of other ethnic groups in Nigeria. Stature is one of the various parameters of identification for establishing individuality of the person (Nemade et al., 2015). The cephalic indices attributed to a complex interaction between genetic and environmental factors (Kassai et al., 1993) and the racial characters are best defined in the skull (Oladipo et al., 2009).

Estimation of status is one of the biological profiles used in the identification of individuals in cases of mass disasters, plane crash, fatal auto crash, bombing, homicides and in crime investigations (Jervas et al., 2015).

The cephalic index was positively correlated with stature ( $p \leq 0.001)$ for Okun males, Okun females and Ebira males of Kogi state except Ebira females which was not significantly correlated with stature. Ewunonu and Anibeze (2013) did estimation of stature from cephalic parameters in south- eastern Nigeria population. The study findings showed that the cephalic indices are positively and significantly correlated with stature. Akhter et al. (2009) worked on stature estimation using head measurements in Bangladeshi Garo adult female. The head measurements were the head length and head circumference in which the circumference was found significantly positive with the stature but the head length did not reach statistically significant level. Jadav and Shah (2004) also worked on estimation of stature from head length. The results showed that the age ranges from 17- 22 years, head length and total height has a significant correlation between them.

The cephalic indices were observed not to be sexually dimorphic among the males and females of Okun and Ebira ethnic groups of Kogi state in Nigeria. The cephalic indices were observed to be sexually dimorphic among Itsekiri however no such difference exists among
Urhobo (Oladipo et al., 2009). Another study on Ogonis in Nigeria, the cephalic indices was observed to be sexual dimorphic (Oladipo et al., 2009). Variation in cephalic index between and within population could have been attributed to a complex interaction between genetic and environmental factors (Kassai et al., 1993).

In this study, $87.2 \%$ of the Ebira male population was seen to have a doliocephalic head shape type, $82.0 \%$ of the Ebira female population also seen to have a doliocephalic head shape type while $48.8 \%$ of Okun males were mesocephalic and $44.1 \%$ of the Okun females were also mesocephalic head type. The predominant head shape type for the Ebira and Okun ethnic were doliocephalic and mesocephalic mixed with doliocephalic respectively. The males in both ethnic groups had higher cephalic indices than females but were not statistically significant. The both sexes of each ethnic group fell under the same head shape type.

Oladipo and Olotu (2006) carried out a study on cephalic indices of Igbos and Ijaw ethnic groups, the Ijaw males are in brachycephalic group while the Ijaw females are in mesocephalic group. Oladipo et al. (2010) did anthropometric studies of cephalic length, cephalic breadth and cephalic indices of the Ibibio of Nigeria. The cephalic index showed that the males and females belong to mesocephalic group. Oladipo et al. (2009) did also anthropometric studies of cephalic indices of the Ogonis in Nigeria, the both sex belonged to brachycephalic population.

In conclusion, the predominant head shape type for the Ebira and Okun ethnic were doliocephalic and mesocephalic mixed with doliocephalic respectively. The males in both ethnic groups had higher cephalic indices than females but were not statistically significant. The both sexes of each ethnic group fell under the same head shape type. The relationship between the head shape type and stature of both sexes of the two ethnic groups were significant that is better predicted except for Ebira females. Ethnic 
groups in the same climatic factors does not have much differences in their cephalic indices based on previous works. For more research work, studies should be carried out on other populations to possibly determine the Financial disclosure: None. relationship between the cephalic indices and height of subjects in that population group and also determine the head shape type associated with that population group.

Conflict of Interest: There is no conflicts of interest regarding the publication of this paper

\section{REFERENCES}

1. Akhter Z, Begum JA, Banu LA, Alam MM, Hossain SA, Amin NF, Uddin MM, Yasmin QS. 2009. Stature estimation using head measurements in Bangladeshi Garo adult females. Bangladeshi J Ana 7: 101- 104.

2. Danborno B, Asala SA, Ekanem UE. 1997. Craniometrics study and derived indices in Nigerians. West African J Ana 5:20.

3. Ewunonu EO, Anibeze CIP. 2013. Estimation of stature from cephalic parameters in SouthEastern Nigerian population. J Sci Inno Res 2:425-432.

4. Iscan, MY. 2001. Global forensic anthropology in the $21^{\text {st }}$ century. Forensic Sci Intl 117: 1- 6.

5. Iscan MY.2005. Forensic anthropology of sex and body size. Forensic Sci Intl 147: 107- 112.

6. Jervas E, Anibeze CIP, Uloneme GC and Anyanwu GE. (2015). Stature estimation of the Igbo using caphalo- facial anthropometry. J Fore Res 6: 295.

7. Kassai KLC, Richard T, Brown T.1993. Comparative study of craniofacial morphology in Japanese and Australian Aboriginal population. Hum Bio 65:821 -834.

8. Kelly KM, Littlefield TR, Pomatto JK, Riphley CE, Beals SP, Joganic EF. 1999. Importance of early recognition and treatment of deformation plagiocephaly with orthotic cranioplasty. The Cleft Palate- Craniofacial J 36:127-130.

9. Nair SK, Anjankar VP, Singh S, Bindra M, Satpathy DK. 2014. The study of cephalic index of medical students of Central India. Asian J Pharm sci 4:48-50.

10. Nemade P, Medha A, Nemade A. 2015. Regression analysis on stature estimation from cephalic dimensions. Indian J Basic and Applied Med Res 4:298- 312.

11. Oladipo GS, Olotu JE. 2006.Anthropometric comparison of cephalic indices between the Ijaw and Igbo tribes. Global J Pure and Applied Sci 12:137- 138.

12. Oladipo GS, Paul CW. 2009. Anthropometric comparison of cephalic indices between the Urhobo and Itsekiri ethnic groups of Nigeria. Global J Pure Applied Sci 15: 65-67.

13. Oladipo GS, Olotu JE, Suleiman Y. 2009. Anthropometric studies of cephalic indices of Ogoni in Nigeria. Asian J Med Sci 1:15-17.

14. Oladipo GS, Okoh PD, Isong EE. 2010. Anthropometric studies of cephalic length, cephalic breadth and cephalic indices of the Ibibios of Nigeria. Asian J Med Sci 2:104- 106.

15. Shah GV, Jadhav HR. 2004. The study of cephalic index in students of Gujarat. J Ana Soc India 53: 20- 21.

16. Williams P, Dyson M, Dussak JE, Bannister LH, Berry MM, Collins P, Ferguson MWJ. 1995. Gray's anatomy. In. Skeletal system. 38th Ed. London, Elbs with Churchill Livingston pp. 607-12. 